\title{
THE EFFECT OF GINGER EXTRACT CONSUMPTION ON REDUCING MORNING SICKNESS IN FIRST TRIMESTER OF PREGNANT WOMEN AT PRATAMA MARIANA CLINIC MEDAN, NORTH SUMATRA
}

\author{
Nurhidaya Fitria, Ida Lestari Tampubolon
}

Helvetia Institute of Health, Sumatera Utara

\begin{abstract}
Background: Nausea and vomiting are common in pregnant women, and the condition may be a mild or severe disabling disease. Nausea and vomiting are common in the early stages of pregnancy, affecting 70-80\% of pregnant mothers. In most women, vomiting begins between 47 weeks of pregnancy. Nausea and vomiting are usually mild and self-limiting, but some mothers have a deeper course and cause pregnancy vomiting. This study aimed to analyze the effectiveness of ginger extract consumption on reducing morning sickness in first trimester of pregnant women at Pratama Mariana Clinic Medan, North Sumatra.

Subject and Method: This was a quasi experiment study with pretest-posttest control group design conducted in Pratama Mariana Clinic, Medan from July to August 2018. A sample of 15 pregnant women. The dependent variable was emesis gravidarum. The independent variable was extract of ginger. The data were collected by observation and analyzed by wilcoxon test.

Result: The extract of ginger is effective to reduce nausea and vomiting in first trimester pregnancy women after ginger extract was given (Mean=1.93; $\mathrm{SD}=0.26$ ) was higher than before $(\mathrm{Mean}=1.20 ; \mathrm{SD}=0.41)$, and it was statistically significant $(\mathrm{p}<0.001)$.

Conclusion: The extract of ginger is effective to reduce nausea and vomiting in first trimester pregnancy women after ginger extract
\end{abstract}

Keywords: Emesis gravidarum, extract of ginger

\section{Correspondence:}

Nurhidaya Fitria. Helvetia Institute of Health, Sumatera Utara. Email: nurhidayafitria@gmail.com. Mobile: o82385317328. 